\title{
The response of liver enzymes to feed restriction and subsequent ad lib. feeding in the laying hen
}

\author{
BY J. PEARCE \\ Department of Agricultural and Food Chemistry, The Queen's University of Belfast, \\ Newforge Lane, Belfast BT9 $5 P X$ and the Department of Agriculture for Northern Ireland
}

$$
\text { (Received I9 November I979- Accepted } 22 \text { January 1980) }
$$

I. The effects of restricted feeding, and ad lib. feeding following food restriction, on hepatic carbohydrate and lipid metabolism in the laying hen were studied.

2. The birds were allocated to four groups and given either 92,84 or $75 \mathrm{~g} / \mathrm{d}$ or allowed ad lib. access to food.

3. Food restriction significantly reduced liver total lipid content compared with ad lib.-fed control birds and this was reflected in reduced hepatic lipogenic enzyme activities.

4. When birds from the restricted regimens were allowed free access to food they initially consumed more food than the control group but after 2 weeks of ad lib. feeding the food consumptions of the birds in all the groups were similar.

5. Concomitant with the increase in food intake there were also increases in liver lipid content and hepatic lipogenic enzyme activities. After i $8 \mathrm{~d}$ of ad lib. feeding these measurements were similar in the previously restricted birds and the ad lib.-fed control group.

6. Despite these effects on lipid metabolism, food restriction, and the subsequent release from food restriction, had no significant effects on the specific activities of the glycolytic enzymes examined.

7. Although there were large increases in liver lipid content following release from feed restriction no birds died from, or showed any of the symptoms of, fatty liver-haemorrhagic syndrome. This suggests that, in the absence of any other factor which may be involved in the syndrome, these high liver lipid contents were not, alone, sufficient to cause FLHS. The results also indicate that free access to food following food restriction is unlikely to be a major factor in initiating the syndrome.

It is established that the pattern of food intake by meal-feeding, ad lib. feeding, fasting or refeeding after a fast results in significant alterations in the metabolism of both mammals (Leveille, 1972) and birds (Pearce, 1974). One aspect of food intake on which there is little information is that of restricted feeding although it has been reported that food restriction in the laying hen has no effect on the activities of various enzymes concerned with hepatic lipid and carbohydrate metabolism (Balnave, I975; Pearce \& Jackson, 1976).

It has been suggested that the pattern of food intake in the fowl can predispose the laying hen to the fatty liver-haemorrhagic syndrome (FLHS). It has been shown that when the laying hen is released from restricted feeding regimens it consumes excess food (Wolford \& Polin, $1972 a$; Polin \& Wolford, 1973). This may cause excess lipid deposits in the liver and may predispose the hen to the syndrome. The present investigation was carried out to investigate the effects of restricted feeding on aspects of hepatic lipid and carbohydrate metabolism and also the possibility of inducing FLHS by allowing birds on a restricted regimen free access to the diet.

\section{MATERIALS AND METHODS}

Two hundred and eight light hybrid pullets (Shaver 288) were used in this experiment. These birds were 25 weeks old at the start of the experiment. They were allocated at random to four experimental groups each of fifty-two birds and each group was fed one of the four dietary regimens. The control group (treatment I) was allowed free access to the food (average intake IOI $\mathrm{g} / \mathrm{d}$ ) and the other three groups were restricted to either 92 (treatment 2), 84 (treatment 3 ) or $75 \mathrm{~g} / \mathrm{d}$ (treatment 4 ). The composition of the diet used is given in Table 
Table I. Composition $(\mathrm{g} / \mathrm{kg})$ of diet

$\begin{array}{lc}\text { Ground maize } & 725 \\ \text { Soya-bean meal } & 75 \\ \text { Fish meal } & 75 \\ \text { Dried grass meal } & 25 \\ \text { Ground limestone } & 75 \\ \text { Dicalcium phosphate } & 20 \\ \text { Sodium chloride } & 2 \cdot 5 \\ \text { Vitamin-mineral supplement } & 2 \cdot 5 \\ \text { Dry matter } & 892 \\ \text { Crude protein } \dagger & 157 \\ \text { Lipid } & 32 \cdot 4 \\ \text { Determined metabolizable energy }(\mathrm{MJ} / \mathrm{kg}) & 12.62\end{array}$

* The vitamin-mineral supplement provided $(\mathrm{mg} / \mathrm{kg}$ diet): retinol I $\cdot 8$, cholecalciferol 75 , riboflavin $2 \cdot 5$, $\alpha$-tocopherol 3.0, menadione sodium bisulphite $2 \cdot 0$, nicotinic acid 10.0 , pantothenic acid 5.0 , cyanocobalamin $2 \cdot 0 \mu \mathrm{g}$, choline chloride 100 , copper 8 , iron 16 , manganese 80 , zinc 60 , cobalt $3 \cdot 0$, iodine $2 \cdot 5$.

+ Nitrogen $\times 6.25$.

I. Throughout the experiment the birds were housed in individual cages and water was provided ad lib.

During the first four $28 \mathrm{~d}$ periods individual records were kept of egg weight, egg numbers and food intake for each hen. Egg production was recorded daily and egg weight was recorded three times per week. Body-weight was noted at the beginning of the first experimental period and was also recorded at the end of each $28 \mathrm{~d}$ period for the duration of the experiment. After 16 weeks (four $28 \mathrm{~d}$ periods) on the restricted feeding regimens all the birds were fed ad lib. to examine the effects of fasting-refeeding on the incidence of FLHS.

After both 8 and 16 weeks on these dietary regimens four birds from each treatment were killed for the assessment of liver weight and liver total lipid content and hepatic enzyme activities. At these times other birds from each treatment were allowed free access to food and four birds from each treatment group were killed after 2, 4 and $18 \mathrm{~d}$ of ad lib. feeding and the same determinations made.

These birds were killed by decapitation and their livers were rapidly removed, chilled and cell-free extracts prepared in $0 . \mathrm{I}$ M-potassium phosphate buffer, $\mathrm{pH} 7.0$, containing 7 mM-mercaptoethanol as previously described (Balnave \& Pearce, 1976). The activities of ATP citrate (pro-3S)-lyase (EC 4.I.3.8) and malate dehydrogenase (decarboxylating) $\left(\right.$ NADP $\left.^{+}\right)$(EC I.I.I .40) were assayed as previously described (Balnave \& Pearce, 1976) and 6-phosphofructokinase ( $E C$ 2.7.I . II), fructose bisphosphate aldolase ( $E C$ 4.1.2. I3) and pyruvate kinase (EC 2.7. . .40) were determined as described by Pearce \& Carr (1969). These assays were carried out at $40^{\circ}$ using a Unicam SP 800 recording spectrophotometer and in all instances the reported activities were linear with respect to time and the protein contents of the extracts.

The protein contents of the cell-free extracts were determined using the Biuret method (Layne, 1957) and the liver total lipid contents by the method of Folch et al. (1957).

The results were assessed by analysis of variance.

\section{RESULTS}

The effects of food restriction on various egg production measurements and body-weight during the four $28 \mathrm{~d}$ periods of restricted feeding are shown in Table 2 . The ad lib. food consumption of the birds had been assessed during the pre-experimental period to be IOI $\mathrm{g} / \mathrm{d}$. However over this 16 week period it was found that the mean daily food intake of birds fed ad lib. (treatment I) was I $2.5 \mathrm{~g} / \mathrm{d}$ so that the extents of restriction of birds on 
Table 2. The effects of food restriction on various egg production measurements during the I 6 week recording period

(Mean values for thirty-six observations)

Treatment ...
Feeding regimen $(\mathrm{g} / \mathrm{d}) \ldots$
Initial body-wt $(\mathrm{g})$
Final body-wt $(\mathrm{g})$
Change in body-wt $(\mathrm{g})$
Mean total food intake $(\mathrm{kg})$
Mean total no. of eggs
Mean egg wt $(\mathrm{g})$
Mean total egg wt $(\mathrm{kg})$
Mean percentage production
Mean food conversion
(kg eggs $/ \mathrm{kg}$ food)

$\begin{array}{cc}1 & 2 \\ \text { ad lib. } & 92 \\ 1582 & 1617 \\ 1851 & 1828 \\ 269 & 210 \\ 12.60 & 10 \cdot 30 \\ 100 \cdot 2 & 88 \cdot 8 \\ 58 \cdot 1 & 56 \cdot 0 \\ 5 \cdot 81 & 4.94 \\ 89.5 & 79 \cdot 3 \\ 2.17 & 2.08\end{array}$

3
84
1645
1824
185
$9 \cdot 41$
$81 \cdot 1$
$55 \cdot 6$
$4 \cdot 48$
$72 \cdot 4$
$2 \cdot 08$

$\begin{array}{ccc}4 & \text { SEM } & \begin{array}{c}\text { Statistical } \\ \text { significance } \\ (F \text { test })\end{array} \\ 75 & (140 \text { df }) & \text { NS } \\ 1606 & 25.7 & \text { NS } \\ 1765 & 36.4 & P<0.01 \\ 152 & 22.6 & P<0.001 \\ 8.40 & 0.086 & P<0.001 \\ 71.7 & 2.90 & P<0.005 \\ 56.6 & 0.60 & P<0.05 \\ 4.06 & 0.154 & P<0.001 \\ 64.0 & 2.59 & P<0.001 \\ 2.08 & 0.074 & \text { NS }\end{array}$

NS, not significant.

Table 3. Average daily food consumption $(g)$ following release from restricted feeding for 16 weeks

(Mean values for twenty observations)

Treatment ...

Feeding regimen $(\mathrm{g} / \mathrm{d}) \ldots$

Period of ad lib. feeding (d)

$0-7$
$7-14$
$14-42$

2
92
$124 \cdot 6$
$120 \cdot 6$
$118 \cdot 8$

3
84
$124 \cdot 4$
$129^{*} 0^{*}$
$124^{\circ}$

3

ad lib.

116.3

I 20. I

4
75
$122 \cdot 4$
$121 \cdot 4$
$118 \cdot 6$

SEM (76 df)

3:38

$2 \cdot 77$

2.46

- Values were significantly different from those for treatment $1(P<0.05)$.

treatments 2, 3 and 4 were greater than originally planned. It can be seen in Table 2 that food restriction resulted in significant reductions in the mean egg weight and the mean number of eggs (and therefore in the mean total egg weight and the mean percentage egg production). The efficiency of food utilization was improved by the three restricted feeding regimens but this did not attain statistical significance compared with the birds fed ad lib. Body-weight gain over the course of the experiment was also significantly affected by restricted feeding and there was a progressive reduction in body-weight gain as a consequence of the progressive reduction in food intake.

The effects of varying degrees of food restriction and subsequent ad lib. access to food on liver weight, liver total lipid content and hepatic enzyme activities were investigated after the birds had been on food-restriction regimens for both 8 and I 6 weeks. Similar results were obtained on both occasions and so only the observations made in one instance (after I6 weeks of food restriction) are given.

It can be seen that when the birds were released from food restriction their ad lib. food intakes were greater than for the control group (treatment $\mathrm{I}$ ). During the first $7 \mathrm{~d}$ of $a d$ lib. feeding the food consumptions of birds from treatments 2,3 and 4 were 5-7\% greater than for the control birds although the differences were not statistically significant. During the next $14 \mathrm{~d}$ period the food consumptions of these groups were again greater than for the control group and in the instance of birds from treatment 3 their average daily food intake was greater than for the control birds. After this time it can be seen (Table 3) that the food consumptions of all the birds were similar.

Food restriction resulted in a slight, but non-significant reduction, in liver weight (Table 
Table 4. Effects of food restriction for 16 weeks and release from restriction on liver weight and liver lipid content

(Mean values for four observations, SEM (48 df) liver wt 0.24, liver lipid content 2-29)

Treatment ...

Feeding regimen $(\mathrm{g} / \mathrm{d}) \ldots$

Period of ad lib.

feeding (d)

0

2

4

18

0

Wt $(g / 100 \mathrm{~g}$ body $\mathrm{wt})$
Lipid content $(\mathrm{g} / 100 \mathrm{~g}$ liver $)$
Wt $(\mathrm{g} / 100 \mathrm{~g}$ body $w t)$ Lipid content $(\mathrm{g} / \mathrm{I} 00 \mathrm{~g}$ liver)

Wt (g/100 g body wt)

Lipid content ( $\mathrm{g} / \mathrm{I} 00 \mathrm{~g}$ liver)

Wt (g/100 g body wt)

Lipid content ( $\mathrm{g} / 100 \mathrm{~g}$ liver) ad lib.

92

$2 \cdot 24$

$17 \cdot 15$

$2 \cdot 70$

18.85

2.65

18.90

$2 \cdot 50$

19.93

1.84
$7.65^{* *}$
$3.55^{*}$
22.71
3.17
$34.91^{* * *}$
$3.54^{* *}$
15.08

4

75

$1 \cdot 82$ $6.93^{* *}$

$3 \cdot 54^{*}$

23.99

$3.80^{* *}$

$31 \cdot 65^{* * *}$

$2 \cdot 54$

$14 \cdot 77$

Values were significantly different from those for treatment $\mathrm{I}$ : *P<0.05, ** $P<0.01, * * P<0.001$.

4) but when food restriction was removed and the birds were allowed free access to food there were large increases in liver weight. After $2 \mathrm{~d}$ of $a d$ lib. feeding the livers from birds previously restricted to $93 \mathrm{~g} / \mathrm{d}$ (treatment 2 ) and $75 \mathrm{~g} / \mathrm{d}$ (treatment 4 ) were significantly heavier than those of the control group (treatment 1 ). Liver weight generally increased further in the birds released from the restricted regimens after $4 \mathrm{~d}$ of ad lib. feeding and after $18 \mathrm{~d}$ the liver weights of birds from treatments 3 and 4 were not significantly different from those of the control group (treatment $I$ ).

The effects of the dietary treatments on liver total lipid content also followed a similar pattern (Table 4 ) but the response was more pronounced. Restricted feeding (treatments 2 , 3 and 4 ) resulted in a significant reduction in liver lipid content compared with controls fed ad lib. Birds from treatments 2, 3 and 4 showed significant increases in liver lipid content after $2 \mathrm{~d}$ of free access to food compared with the values during restricted feeding but these were not significantly different from the liver lipid content of the $a d$ lib.-fed controls. There were further increases in liver lipid content after $4 \mathrm{~d}$ of ad lib. feeding and for treatments 2, 3 and 4 they were greater than in the control group. After $18 \mathrm{~d}$ the liver lipid contents in the four groups were not significantly different.

The changes in liver total lipid contents were reflected in the specific activities of the hepatic lipogenic enzymes, ATP citrate (pro-3S)-lyase and malate dehydrogenase (decarboxylating) (NADP+). These enzymes showed significant responses to both food restriction and subsequent release from food restriction. The birds on the food restriction regimens (treatments 2,3 and 4 ) had lipogenic enzyme activities which were lower than the ad lib.-fed controls and for malate dehydrogenase (decarboxylating) (NADP ${ }^{+}$) this reduction was significant (Table 5). Within $2 \mathrm{~d}$ of the removal of food restriction there was a marked increase in the specific activity of these enzymes. In the instance of ATP citrate (pro-3S)-lyase there was a significantly greater specific activity in liver extracts from birds previously restricted to $76 \mathrm{~g} / \mathrm{d}$ (treatment 4 ) than those from birds fed ad lib. (treatment $\mathrm{I}$ ). After $4 \mathrm{~d}$ of being allowed free access to food the effect was greater and the specific activity of ATP citrate (pro-3 $S$ )-lyase was significantly greater in birds from treatments 2, 3 and 4 than in those from treatment $\mathrm{I}$. After $18 \mathrm{~d} a d$ lib. feeding there were no significant difference 3 in enzyme specific variety in any of the groups of birds although the activities observed in birds from treatments 2,3 and 4 were significantly greater than those obtained during restricted feeding. 
Table 5. Effects of food restriction for $\mathrm{I} 6$ weeks and release from restriction on hepatic lipogenic enzyme activities ( $\mathrm{nmol}$ substrate metabolised/min per $\mathrm{mg}$ protein in the extracts)

(Mean values for four observations, SEM (48 df) ATP citrate (pro-3S)-lyase $(E C 4.1 .3 .8) 2.022$, Malate dehydrogenase (decarboxylating) (NADP $\left.{ }^{+}\right)(E C$ I I I I .40) I8.21)

Treatment ...

Feeding regimen $(\mathrm{g} / \mathrm{d}) \ldots$

$\begin{array}{cccc}\text { I } & 2 & 3 & 4 \\ \text { ad lib. } & 92 & 84 & 75 \\ 16 \cdot 59 & 11 \cdot 35 & 10 \cdot 10 & 12 \cdot 28 \\ 215 \cdot 3 & 163 \cdot 5 & 148 \cdot 3^{*} & 154^{* *} \\ 17 \cdot 30 & 16 \cdot 30 & 21 \cdot 90 & 24 \cdot 36^{*} \\ 203 \cdot 1 & 256 \cdot 7^{*} & 233 \cdot 0 & 249 \cdot 6 \\ 18 \cdot 05 & 31 \cdot 41^{* * *} & 28 \cdot 27^{* * *} & 34 \cdot 49^{* * *} \\ 209 \cdot 5 & 287 \cdot 9^{* *} & 285 \cdot 5^{* *} & 292 \cdot 4^{* *} \\ 17 \cdot 48 & 17 \cdot 75 & 19 \cdot 43 & 19 \cdot 18 \\ 213 \cdot 5 & 219 \cdot 3 & 226 \cdot 4 & 226 \cdot 4\end{array}$

Period of ad lib.

feeding (d) o

2

4

18
ATP citrate (pro-3S)-lyase Malate dehydrogenase (decarboxylating) (NADP ${ }^{+}$)

ATP citrate (pro-3S)-lyase Malate dehydrogenase (decarboxylating) (NADP ${ }^{+}$)

ATP citrate (pro-3S)-lyase Malate dehydrogenase (decarboxylating) (NADP ${ }^{+}$

ATP citrate (pro-3 $S$ )-lyase Malate dehydrogenase (decarboxylating) (NADP ${ }^{+}$
Values were significantly different from those for treatment I: ${ }^{*} P<0.05, * * P<0.01,{ }^{* * *} P<0.001$.

The specific activity of malate dehydrogenase (decarboxylating) (NADP+) varied in a similar manner (Table 5). After $2 \mathrm{~d}$ of ad lib. feeding there was a substantial increase in the specific activity of this enzyme in birds from treatments 2, 3 and 4 and in the instance of birds from treatment 2 this increase attained statistical significance. After $4 \mathrm{~d}$ of ad lib. feeding there was a further increase in specific activity and the values obtained for treatments 2, 3 and 4 were all significantly greater than for the control group (treatment I). After $18 \mathrm{~d}$ of free access to food there were no significant differences in enzyme activity between any of the treatment groups but the results for birds from treatments 2, 3 and 4 were significantly greater than those obtained during restricted feeding.

Although there were changes in lipogenic enzyme activities the glycolytic enzymes, 6-phosphofructokinase, fructose bisphosphate aldolase and pyruvate kinase, which were also examined, showed no significant variations in specific activity as a result of the various dietary treatments.

It was also found that despite the huge increases in liver total lipid content resulting from the release of birds from food restriction there were no deaths from FLHS and no liver haemorrhages were seen in any of the birds killed for the enzyme studies. After the birds were removed from food restriction, following 16 weeks of restricted feeding, the remaining twenty birds were allowed free access to food for a further 12 weeks. During this period there were no deaths from FLHS and none of the birds exhibited symptoms characteristic of the syndrome.

\section{DISCUSSION}

Although food was restricted all the dietary treatments were production regimens where all the birds were laying and over the course of the experiment the birds gained weight. The effects of restricted feeding on body-weight gain, egg production, egg weight and food conversion were in general agreement with previous observations (Jackson, 1969, 1970, 1972; Pearce \& Jackson, 1976).

The effects of food restriction on liver weight were also in accord with previous results (Pearce \& Jackson, 1976) in that there was no statistically-significant effect on liver weight 
(expressed relative to body-weight) although there was a slight reduction compared with ad lib.-fed birds. There was, however, a significant reduction in liver total lipid content as a result of restricted feeding and this was also reflected in the specific activities of the hepatic lipogenic enzymes, ATP citrate (pro-3 $S$ )-lyase and malate dehydrogenase (decarboxylating) $\left(\mathrm{NADP}^{+}\right)$. The activities of both of these enzymes were reduced compared with the values in ad lib.-fed control birds and in the instance of malate dehydrogenase (decarboxylating) $\left(\mathrm{NADP}^{+}\right)$the reduction was statistically significant. The effects of food restriction on liver lipogenic enzyme activities were greater in this study than previously observed (Pearce \& Jackson, 1976). This may be related to the fact that in the present work both the energy and protein intakes were restricted whereas in the earlier study (Pearce \& Jackson, 1976) only the energy component was restricted and the protein intake was unaltered. However, restricted feeding had no significant effect on the specific activities of the hepatic glycolytic enzymes examined which is in agreement with earlier work (Pearce \& Jackson, 1976).

When birds from food restriction regimens were allowed free access to food there was a very rapid increase in hepatic lipogenic enzyme activity for up to $4 \mathrm{~d}$ after food restriction was removed and the extent of the increase in activity was similar in all the birds irrespective of the extent of food restriction to which they had been subjected. The enzyme specific activities were 57-91 \% and 36-40\% greater for ATP citrate (pro-3S)-lyase and malate hydrogenase (decarboxylating) (NADP+), respectively, than for the control birds fed $a d$ lib. $4 \mathrm{~d}$ after the removal of food restriction. Shapira et al. (1978 $a, b)$ similarly observed increases in the specific activities of hepatic lipogenic enzymes in overfed laying hens and Japanese quail (Coturnix coturnix japonica) compared with birds fed ad lib. The present results are in accord with the results of Goodridge (1968) who showed that in chickens refed following a fast, lipogenic enzyme activities do not show the huge 'overshoot' which has been observed in fasted-refed rats (Romsos \& Leveille, 1974). The response of glycolytic enzymes, 6-phosphofructokinase, fructose bisphosphate aldolase and pyruvate kinase to restricted feeding and release from food restriction also appears to be more limited in the chick than in the rat because no significant effects on enzyme specific activities were seen throughout the experiment whereas in the rat fasting and refeeding after a fast has marked effects on the specific activities of 6-phosphofructokinase, fructose bisphosphate aldolase (Weber et al. 1966) and pyruvate kinase (Weber et al. 1967).

The induction of FLHS has been correlated with excess energy intake. A number of studies (Wolford \& Polin, 1972 b, 1974; Polin \& Wolford, 1973, 1976) have shown that FLHS can be induced by force-feeding and the incidence of the syndrome is correlated with the energy intake. Excess food intake also occurs when birds on restricted feeding regimens are allowed free access to food (Polin \& Wolford, 1972) and this results in fatty metamorphosis of the liver. It has been suggested (Polin \& Wolford, 1973) that the release of birds from restricted feeding could result in long-term excessive eating habits causing excess liver lipid deposits which may predispose the hen to FLHS. In the studies of Polin \& Wolford (I972) and Wolford \& Polin (1972 a) birds consumed 10\% more food for at least 8 weeks following their release from restricted feeding compared with birds fed ad lib. throughout. This procedure was not successful as an experimental method to induce the syndrome and Wolford \& Polin ( 1972 a) suggested that an 8-week refeeding period following restriction was not long enough for FLHS to be seen. In the present experiment excessive food consumption was observed in birds released from food restriction but the extent of over-eating was not as great as reported by Polin \& Wolford (1972) and Wolford \& Polin $(1972 a)$ and the over-consumption only continued for approximately 3 weeks following the release from food consumption. Concomitant with the increases in food consumption and in hepatic lipogenic enzyme activity following the removal of food restriction there was approximately a 4 -fold increase in liver lipid content $4 \mathrm{~d}$ after being allowed free access to 
food; at this time the liver lipid contents for birds released from food restriction were 62-85\% greater than for control birds. Despite this large increase in liver lipid content there were no deaths from FLHS and no haemorrhages were seen in the livers of any of the birds killed for the enzyme studies. This suggests that, in the absence of any other factor which may affect membrane fragility and cause haemorrhaging, the increased liver lipid content which arises as a result of release from food restriction was not, alone, sufficient to initiate FLHS.

Similarly during the rest of the experiment when the previously-restricted birds were fed $a d$ lib. there were no deaths from FLHS and none of the birds showed any symptoms of the condition. The present results are in agreement with those of Wolford \& Polin (1972 $a, b)$ and show that the restricted-refeeding regimen did not induce FLHS. The results also suggest that food restriction is unlikely to be a major factor in initiating FLHS.

The author wishes to thank the Trustees of the Agricultural Research Institute, Hillsborough, N. Ireland, for providing facilities for the laying trial and Mr A. H. Johnson for technical assistance with the biochemical studies.

\section{REFERENCES}

Balnave, D. (1975). Br. J. Nutr. 33, 439.

Balnave, D. \& Pearce, J. (1976). Br. Poult. Sci. 17, 627.

Folch, J., Lees, N. \& Sloane-Stanley, C. H. (I957). J. biol. Chem. 226, 497.

Goodridge, A. G. (1968). Biochem. J. 108, 667.

Jackson, N. (I969). 42nd A. Rep. agric. Res. Inst. N. Ire. p. 25.

Jackson, N. (1970). Br. Poult. Sci. I1, 93.

Jackson, N. (1972). J. Sci. Fd Agric. 23, 413.

Layne, E. (1957). Meth. Enzym. 3, 450.

Leveille, G. A. (1972). Nutr. Rev. 30, 151.

Pearce, J. (1974). Wld's Poult. Sci. J. 30, I 15.

Pearce, J. \& Carr, N. G. (I969). J. gen. Microbiol. 54, 451.

Pearce, J. \& Jackson, N. (1976). Nutr. Rep. int. 14, 73.

Polin, D. \& Wolford, J. H. (I972). Poult. Sci. 5I, I 109.

Polin, D. \& Wolford, J. H. (1973). Fedn Proc. Fedn Am. Socs exp. Biol. 32, 1720.

Polin, D. \& Wolford, J. H. (1976). Poult. Sci. 55, 325.

Romsos, D. R. \& Leveille, G. A. (1974). Adv. Lipid Res. 12, 97.

Shapira, N., Nir, I. \& Budowski, P. (1978a). Br. J. Nutr. 39, I51.

Shapira, N., Nir, I. \& Budowski, P. (1978b). Br. J. Nutr. 39, 289.

Weber, G., Lea, M. A., Convery, H. J. H. \& Stamm, N. B. (1967). Adv. Enzyme Reg. 6, I0I.

Weber, G., Singhal, R. L., Stamm, N. B., Lea, M. A. \& Fisher, E. A. (1966). Adv. Enzyme Reg. 4, 59.

Wolford, J. H. \& Polin, D. (1972a). Poult. Sci. 51, 1707.

Wolford, J. H. \& Polin, D. (I972 b). Feedstuffs 44, $4 \mathrm{I}$.

Wolford, J. H. \& Polin, D. (I974). Poult. Sci. 53, 65. 